\title{
PROGRESS IN PEDIATRICS
}

\author{
REVIEW OF SYPHILIS WITH ESPECIAL RELATION TO \\ HEREDITARY SYPHILIS \\ HARVEY PARKER TOWLE, M.D. \\ BOSTON
}

The serum tests and the salvarsan and neosalvarsan therapy almost completely dominate the current literature on syphilis. The tremendous volume is probably, in part, due to the lack of restraint from too hastily "rushing into print" imposed by definite knowledge. Such articles as showed at least something of their plan of construction were selected for this review. Those giving no data to support their arguments were considered as mere expressions of personal opinion and accordingly not suitable for our purpose.

While, in practice, it is nearly impossible to consider the serum test or the salvarsan and neosalvarsan therapy apart from one another, it was thought that the trend of current thought would be shown more clearly if the two topics were reviewed independently, although it was realized that the decision made much repetition inevitable. Consequently, the serum test has been assigned to Part I, and salvarsan and neosalvarsan to Part II. In selecting material, it was made the rule that the chosen communication must bear on the question of Hereditary Syphilis. Otherwise, no distinction was drawn between acquired and hereditary syphilis, the reason being that the action of the spirochetes is the same, fundamentally, in both forms of the disease.

Part I-The Serum Test

SPECIFICITY AND VAGARIES OF THE WASSERMANN TEST

It is accepted to-day that, strictly speaking, the Wassermann test is not specific for syphilis. The record of non-syphilitic affections which have reacted more or less regularly to the Wassermann test has already grown to considerable length. Field ${ }^{39}$ now adds a report of 8 positive reactions in 12 cases of lead-poisoning. In 5 , his most careful investigation failed to discover another symptom, even slightly suspicious. Field's explanation of the occurrence is that the toxic action of the lead produced reaction-causing bodies which were of the same nature as the positively reacting substances created in syphilis by spirochetal activity.

The failure of the Wassermann test and its not infrequent inexplicable vagaries have led many to dispute its claim to invariable reliability. 
In support, they point to such examples as the following: De Buys ${ }^{19}$ made 224 tests in 235 cases of hereditary syphilis and, whenever possible, tested the parents' blood also. It is very significant that the father's blood invariably gave the same reaction to the test as the blood of the mother. In nine children, the results were irregular and inexplicable. The serums of two were negative, notwithstanding positive tests in all four parents. On the other hand, four children were negative while their four mothers were positive. Three children gave positive results, yet their mothers were negative. One mother and one twin had negative sera, but the other twin was positive. With a demonstrated abundance of treponema present we expect a positive reaction. De Buys reports a negative W. R. in an 18-months-old child, although there were abundant spirochetes in the scrapings taken from the condylomata. De Buys believes that these various, unexpected results were probably due to faulty technic and were not to the discredit of the test itself.

\section{SOURCES OF ERROR}

The difficult technic of the Wassermann test is, admittedly, a constant menace to accurate results. The literature shows that the possibilities of errors originating from this source are not inconsiderable. Bailey's ${ }^{7}$ investigations, confirmed later by Dexter and Cumner, ${ }^{31}$ demonstrated that human serums occasionally contain a natural hemolytic substance, which, without artificial aid, is able to interfere with the reaction and, therefore, with its accuracy. They even think that the explanation of some of the inexplicable vagaries of the test is to be found in the unsuspected presence of this hemolytic substance. They conclude that no test can be considered scientifically accurate unless the presence or absence of this natural substance has been determined and appropriate measures taken to remove it.

1. Influence of Medicaments on the Reaction.-According to KingSmith, ${ }^{68}$ we introduce a possible source of error if the blood for the serum test is taken within thirty-six to seventy-two hours after the administration of salvarsan. Strathy and Bates ${ }^{117}$ say that the W. R. is of little value if the serum is obtained within six months of the last mercurial treatment.

Mayer ${ }^{81}$ reports that, in the test-tube, salvarsan, independently of its spirillicidal action, caused previously positive sera to be changed to negative. He found that injections of salvarsan produced a negative reaction in healthy rabbits (whose normal reaction is positive). $\mathrm{He}$ concluded also that salvarsan increases the hemolytic substances in the blood of healthy human beings. From these facts, he draws the final conclusion that a quantitative estimation of the W. R. is necessarily impossible. Lévy-Bing, Dogny and Duroeux ${ }^{72}$ state that salvarsan, 
especially its primary injection, increases the resistance of the blood to hemolysis.

2. The Antigen.--The possible sources of error resident in the use of imperfect and unstandardized reagents are obvious. Keidl and Hurwitz ${ }^{64}$ decided that the results from syphilitic and non-syphilitic antigens are not equally reliable. The syphilitic is the more accurate in their opinion.

3. The Operator and the Clinician.--The personality of the operator or his inadequate training may constitute a possible source of error. I'herefore Kaplan ${ }^{63}$ insists that the possibility shall be avoided by accepting only the results obtained by operators personally known to be competent. That the operator may fail to differentiate accurately between the delicate variations in the shades of the reaction is always a danger. Even more menacing, however, is the possibility that the attending physician may fail to recognize that the clinical value of even an accurate laboratory report is not the same in every case but is, on the contrary, a variable quantity.

\section{THE NATURE OF TIIE SERUM REACTION}

A theory, widely held, is that the positive result of the serum test is due to certain substances, probabiy endotoxins, elaborated by active spirochetes. Cook, ${ }^{26}$ however, will not admit that endotoxins play any part in the production of the reaction. Meyer, ${ }^{86}$ studying the serum reaction from the view-point of drug effects, concluded that salvarsan is a spirochetal poison and that mercury aids the body tissues in their defensive action. Brown ${ }^{15}$ constructed a hypothetical explanation of the Wassermann reaction on the basis of his observations of the clinical results from salvarsan and from mercurial medication. With salvarsan, he says, both the clinical symptoms and the spirochetes in the lesions disappear sooner than the positive serum test. With mercury, on the contrary, the reaction is the first to disappear. Hence, Brown concludes, the positive Wassermann test is due to the products of spirochetal activity. By virtue of its spirillicidal action, salvarsan destroys the syphilitic agent but without affecting the reactivity of the products of previous spirochetal action. The test remains positive. Mercury, on the other hand, acts on the spirochetes indirectly only by first destroying their toxins and encouraging the tissues in their production of defensive substances. Therefore, the positive reaction and not the clinical signs is the first to disappear.

Luetin.-The Noguchi luetin test throws a somewhat negative light on the nature of the bodies which produce the positive Wassermann reaction. Luetin is a substance obtained from pure cultures of several strains of spirochetes. Unlike the Wassermann test, which is most accurate in cases of florid syphilis, the luetin test is said to be most 
reliable in the inactive forms of tertiary, latent and hereditary syphilis. $^{85}$ Gradwohl ${ }^{50}$ says that, whereas the Wassermann reaction is dependent on the infectivity of the invading organisms, the luetin test is a phenomenon of anaphylaxis; of a sensitization of the tissues by the syphilitic virus. When the sensitizing agent disappears the luetin reaction must also disappear. Therefore, if the removal of a cause ever signifies a cure, the failure of the luetin test must indicate the cure of syphilis. Noguchin ${ }^{95}$ is so convinced of the reliability of his luetin test that he considers its failure to obtain a positive reaction a sure sign that syphilis does not exist. He states that the Iuetin reaction is probably caused by products elaborated during a past activity of the treponema.

Cholesterin.-The addition of cholesterin to the antigen, Fordyce ${ }^{42}$ reports, renders the Wassermann test more delicate and, consequently, more valuable. If the statement is subsequently approved, it will indicate that a lipoid substance is concerned in the production of the reaction. Thomas and Ivy, in The Journal of the A. M. A. for January 31, 1914 (p. 36) advocate the aivandonment of artificial antigens for routine clinical use. In the present state of our knowledge, they regard their addition as a step backward. They admit that the cholesterinized extracts may, undoubtedly, give a more cielicate reaction, but find a criticism in the very fact. They say that these artificial antigens react not only to syphilis, but also to non-syphilitic diseases. This, for example, is shown by the 28 per cent. positive reactions occurring in cases of psoriasis reported by Sckamberg and his associates. Thomas and Ivy urge a return to the original Wassermann technic, saying that it is "a very much less serious error to overlook an occasional case of syphilis than to saddle the diagnosis, with all its consequences, on a patient who has ro syphilis."

\section{SALVARSAN REACTION}

The "Salvarsan or Prorocative Reaction" is a diagnostic method consisting of injections of salvarsan in negative, but suspected, cases in order to provoke a positive reaction. All do not agree with Ballenger and Eimer ${ }^{9}$ that the provocative injection is especially useful in the diagnosis of cases of latent and obscure syphilis. The hypothesis underlying the method is, first, that endotoxins are the cause, or at least a cause, of the positive Wassermann reaction; second, that the bodies of the spirochetes contain positive-reaction-producing endotoxins; third, that salvarsan, by its spirillicidal action, destroys hitherto hidden or latent spirochetes and thereby liberates endotoxins which then react to the serum test.

THE BLOOD AND THE REACTION

We would seem justified in expecting to obtain much valuable information from cytology as to the identity of the substances causing the positive reaction. Unfortunately, it has furnished many inferences but few 
positive facts. For example, Fruhwald's ${ }^{45}$ failure to inoculate animals by means of syphilitic blood was thought to indicate that the infectious agent does not circulate freely in the blood and that it therefore cannot be the direct cause of the reaction. $\mathrm{Cook}^{26}$ does not believe that the intensity of the reaction is in any way dependent on the number of spirochetes present. By the same method of argument, it would follow that, because Scholtz and Riebes ${ }^{109}$ could find no salvarsan in the blood four to six hours after an intravenous injection, the substance, salvarsan, is not per se, the exciting cause of the reaction. The findings of Swift and Ellis ${ }^{119}$ that, notwithstanding the failure to demonstrate salvarsan in the blood, the milk of salvarsan-treated mothers has a favorable influence on nurslings, suggests that salvarsan produces curative substances which survive its own disappearance. King-Smith's failure to derive the same satisfaction from this method of treating hereditary syphilis ${ }^{66}$ seems to indicate a less abundant supply of these salvarsan-products in his patients or else a more rapid elimination.

Blood Count.-Hazen ${ }^{53}$ has published carefully prepared tables of the results of 175 differential blood counts in 125 cases of syphilis, all made by the same person and with the same technic. The normal average syphilitic white count was about 7,500, of which 55 per cent. was of neutrophils and 33 per cent. of lymphocytes. Untreated secondary cases showed a slight leukocytosis, the neutrophils being increased both relatively and absolutely. The eosinophil count reached its highest point in cases in the secondary stage. Treatment produced a slight decrease of eosinophils and a slight absolute, but marked relative, increase of lymphocytes, in one case to 65 per cent. Hazen says that the high degree of lymphocytosis might persist for years or the count return to normal in from three to five months. In tertiary syphilis, the differential count was usually not far removed from the normal. There was rarely an increased leukocytosis. Myelocytes were seldom found, even when anemia coexisted. Treatment usually, but not invariably, caused a relative and an absolute increase of lymphocytes. Negroes gave a higher lymphocyte count than whites, although, in late syphilis, the differences grew less pronounced. The highest count was found in cases with the large papular eruptions. In negroes the arerage was 42 per cent. The age of the patient seemed to have very little influence on the leukocyte count except that in the very young the tendency was toward a high neutrophil count and a relatively low percentage of lymphocytes. There was apparently little connection between the degree of the glandular enlargement and the number of lymphocytes. The severe secondary cases yielded a higher total white count and a relatively and absolutely higher neutrophil count than the mild cases. All cases of secondary syphilis which did badly showed, before treatment, a high percentage of neutrophils and a low percentage 
of lymphocytes. On the other hand, all cases with a low neutrophil but a high lymphocyte count did well. Late hereditary syphilis did not necessarily mean that the lymphocyte count was high. 'The existence of an eosinophilia was considered an argument against the diagnosis of syphilis.

Cerebrospinal Serum Test.-The successes and failures of the original Wassermann blood-test have given rise to a number of other serological and microscopical diagnostic measures of which the serological and cytological examination of the cerebrospinal fluid has proved itself the most reliable. The combination of the tests of the blood-serum with examinations of the cerebrospinal fluid is steadily growing in favor.

Fordyce $^{43}$ advocates for diagnostic purposes the combination of the Wassermann test of the blood and the serological and microscopical examination of the spinal fluid. Jeanselme and Vernes ${ }^{61}$ believe that the reaction of the cerebrospinal fluid is largely independent of the blood reaction and is an accurate index of the concentration of the energy of the disease on the nervous system. Ravaut ${ }^{103}$ says that the meninges are involved in 67 per cent. of all cases of secondary syphilis, and, furthermore, without exciting suspicion. When syphilis has invaded the canal, examination of the cerebrospinal fluid will disclose a lymphocytosis, the Wassermann test a positive reaction and the chemical tests an increase of albumen. Ball ${ }^{8}$ considers an increased globulin content and a lymphocytosis of the cerebrospinal fluid as characteristic results of meningeal syphilis. Spiethoff ${ }^{113}$ thinks that the Wassermann test of the cerebrospinal fluid is more delicate than the blood-test. Browning and Lintz ${ }^{\mathbf{1 7}}$ think that their results from injections of the patient's own spinal fluid into the general circulation indicate that the tissues of the spinal canal are stimulated by the syphilitic process to the production of a limited amount of antibodies. Pinkus ${ }^{99}$ accounts for the positive W. R. after salvarsan by its action on accumulations of syphilitic substances in the nerve cells and ganglia. Lévy-Bing, Duroeux and Dogny ${ }^{71}$ apparently believe that the meninges are impenetrable from the general circulation. Either the blood or the cerebrospinal fluid may therefore develop independent symptoms. Swift and Ellis ${ }^{119}$ state that, while the syphilitic agent may perhaps be able to penetrate the meninges from the general circulation, therapeutic substances are not. Lorenz, ${ }^{75}$ however, reports a diminution of the lymphocytosis and of the globulin in the spinal fluid after intravenous injections of salvarsan. Ravaut ${ }^{103}$ says that salvarsan treatment has increased the number of meningeal reactions in syphilis by 20 per cent.

COLLES' LAW IN THE LIGH'T OF THE W. R.

The Colles Law has been used as a standard of criticism ever since the introduction of the Wassermann test method. On the whole, the results with the serum test have been in accord with the general concep- 
tion of the Law. Andronesco and Saratzeano ${ }^{5}$ reported recently that the results of the $W$. R. prove that there are cases of hereditary syphilis with no visible symptoms and other cases of apparently healthy mothers of syphilitic children in which the reaction is the sole evidence of syphilis. In the latter event, the W. R. is stronger in the child than in the mother. Post $^{101}$ believes that the positive tests prove that these seemingly healthy mothers are themselves infected and should be treated accordingly.

\section{TRANSWISSION}

Marshall ${ }^{79}$ argues that the evidence does not justify the renunciation of the doctrine of the possibility of paternal transmission of syphilis without maternal infection. The clinical facts, he says, positively support the theory. The theoretical evidence does not disprove it. Carle ${ }^{22}$ confesses that he once thought that the mother played the chief rôle in the transmission of syphilis. Now, he believes that the majority of cases of hereditary syphilis can be attributed to the father. Engman ${ }^{37}$ denies the possibility of transmitting hereditary syphilis from the father without infection of the mother. De Aja ${ }^{\mathbf{1}}$ believes that transmission attenuates the syphilitic virus. Andronesco and Saratzeano ${ }^{5}$ state that the number of pregnancies has no influence on the intensity of the serum reaction. MacKee ${ }^{i T}$ reports two cases of inherited syphilis in which, contrary to the rule, the disease symptoms were of greater intensity in the second child than in the first.

\section{NATURE OF THE NEGATIVE SERUM REACTION}

Clinical and laboratory researches have enabled us to draw certain fairly definite inferences at least, if not conclusions, as to the nature of the positive serum reaction in syphilis but have failed to increase our understanding of the negative reaction to any extent. The almost complete ignorance of the real meaning of the negative test has caused current opinion to assume the rather curious attitude of denying any value whatever to the negative reaction; that is, to the non-positive result of the serum test, and of proclaiming in the same breath that the negative reaction is the goal of our therapeutic ambition.

\section{VALUE OF THE POSITIVE SERUM TEST}

It is notorious that different operators have often drawn different conclusions from tests of the same serum. Blackfan, Nicholson, Jr., and White say that too small series may lead to radically different conclusions. Last September they repeated the conditions of Churchill's investigations $^{24}$ in which he obtained a positive W. R. in thirty-nine of 101 patients tested. They found but two in the same number of tests. (AM. Jour. Dis. Child., Sept., 1913, p. 162.) In the same issue, Dr. L. Emmet Holt wrote that "it is the consensus of opinion at present that latent as 
well as active syphilis gives a positive response to the Wassermann test." Further along in the article, Dr. Holt speaking of the value of the test, remarked that "Errors due to faulty technic must also be taken into account. 'These are much more common and are almost always on the positive side, so that the children tested are pronounced syphilitic when they are not so." Strathy and Campbell (Ibid., 18\%) report that all of their eighteen cases of hereditary syphilis improved clinically, but that the serum reaction became negative in only two. From their experience, they concluded that the younger the child, the more rapidly treatment influenced the serum reaction.

Kochmheld ${ }^{69}$ says that, while the W. R. may be a valuable clinical help, it is only one link in the chain of evidence and should never be accepted as the sole ground for diagnosis. Gradwohl ${ }^{50}$ does not consider the serum test an infallible diagnostic index. The clinical and serological tests of 1,050 cases of amentia gave such divergent results that Stoner and Kaiser ${ }^{116}$ think that the W. R. has little value, at least in that affection. Müller ${ }^{90}$ found the W. R. positive in two patients who had had no symptoms for two years. Churchill ${ }^{24}$ believes that a positive reaction means syphilis without need of confirmation by other evidence. Nevertheless, he is surprised at the large number of children with no other symptom. IKaplan ${ }^{83}$ feels that it is a grave mistake to make the W. R. the final court of appeal. Welde's report ${ }^{138}$ that he found it very difficult to destroy the positive reaction of hereditary syphilis bears on the question. Post ${ }^{101}$ believes that the unsupported evidence of the serum test is enough to justify the diagnosis of syphilis. Fordyce ${ }^{42}$ says that unreliable results with the serum test method do not accuse the test, but the accuracy of the technic. Because of his belief in its reliability, D'Amato ${ }^{4}$ trusts the serum reaction to reveal the cause of sudden deafness. Barduzzi ${ }^{10}$ thinks that the W. R. is a great help, but must not be taken too seriously. Heidingsfeld ${ }^{56}$ believes in the accuracy of the reaction. $\mathrm{Noguchi}^{96}$ also believes that a positive test means syphilis. Reidl and Geyer ${ }^{106}$ assert that the W. R. is the surest method of detecting syphilis. Objections, they say, are based on errors of technic and of judgment in interpreting the result. Carpenter ${ }^{23}$ does not consider the W. R. as reliable in syphilis of the organs of special sense as in syphilitic disease elsewher'e.

\section{THE POSITIVE TEST AND SPREAD OF SUSPICION}

One result of the clinical use of the serodiagnostic method has been to arouse suspicions of syphilis in unexpected quarters. A positive reaction convinced Biggs ${ }^{13}$ that a case of interstitial keratitis and sudden deafness was due to syphilis. On the unsupported evidence of the W. R., Campbell and Patch $^{20}$ ascribed two cases of chorea to syphilis. For the same reason, Davis ${ }^{\mathbf{3 0}}$ made a diagnosis of congenital syphilis in the case 
of a boy of 16 with a marked general adenopathy, considerable edema of the cheeks and eyelids, especially the right, destruction of the uvula and a part of the soft palate and a pronounced right-sided hydrocele. Flautau, ${ }^{41}$ discussing the etiology of two cases of chorea, says that, despite prevailing opinion, the connection of the disease with syphilis is established by the history, the W. R., and the results of treatment. 'Terzaghi'122 accepted as sufficient proof of its syphilitic origin the unconfirmed evidence of a positive W. R. in a case of alopecia areata in a 10-months-old child. A history of lues in the mother, a positive reaction to the Wassermann test and a prompt response to "mixed treatment" caused Trimble ${ }^{125}$ to diagnose as congenital syphilis the case of a girl of 5 in which there was swelling and pain in the left knee and in which the heel of one foot was so drawn up that only the ball of the foot was used in walking. Cure followed a treatment of one week.

\section{INCREASE IN OUR UNDERSTANDING}

Before leaving the subject of the serum reaction to take up the consideration of salvarsan and neosalvarsan in Part II, it is desired to present, for the sake of comparison, a few conclusions from a previous review of the serum test published in this Journal, September, 1912. The following abstracts are taken from the "recapitulation":

"The Wassermann reaction gives a positive guide in the presence of active cutaneous manifestations, but is not entirely convincing when the cutaneous symptoms are dubious or lacking." "The Wassermann reaction is not specific for syphilis." "The technic is so exceedingly difficult and the sources of error so numerous as to render acceptance of results reported dependent on the qualifications possessed by the maker of the test. . . . The negative reaction has no diagnostic value." "The same laws govern the behavior of the Wassermann reaction in congenital syphilis as in acquired syphilis." "The Wassermann reaction is to be regarded as neither more nor less than a symptom. . . . It is not the period of the disease on which the occurrence of the complement fixation depends, but on the activity of the invading parasite." "A negative Wassermann test is of no value in prognosis. Apparently the persistence of the positive reaction, under certain conditions, has no more value than the negative, as was shown in the discussion of the relation of the test to marriage." "Although the aim, from a therapeutic point of view, is to convert a positive reaction into a negative, so far as the Wassermann reaction is concerned we cannot say whether the invading spirochetes have actually been conquered or only temporarily paralyzed. In short, our understanding of the inner meaning of the Wassermann reaction is incomplete and practically limited to the positive phase of the subject. But our knowledge of even the positive phase lacks perfection."

(To be continued.)

\section{REFERENCES}

1. Aja, Sainz de: Actas dermo-sifilis-graficas, February and March, 1912, No. 2, p. 182 .

2. Aja, Sainz de: Actas dermo-sifilis-graficas, February and March, 1912, No. 2, p. 164 .

3. Almkvist: Dermat. Wchnschr., Jan. 11, 1913, p. 4I.

4. D'Amato: Gior. ital. d. mal. Ven. e. d. pelle, 1912, liii, No. 1, p. 126. 
5. Androneseo and Saratzeano: Presse Med., April 3, 1912.

6. Azura, Jean de: Actas dermo-sifilis-graficas, February and March, 1912, No. 2, p. 174.

7. Bailey: Arch. Int. Med., 1913, ix, No. 5, p. 551.

8. Ball: Jour. Am. Med. Assn., Oct. 5, 1912, p. 1272.

9. Ballenger and Elmer: Med. Rec., New York, Dec. 7, 1912, p. 1024.

10. Barduzzi : Gior, ital. d. mal. ven. e d. pelle, March 21, 1912, p. 17.

11. Beck: München. med. Wehnsehr., Aug. 27, 1912, p. 1905.

12. Beck, J. C.: Ann. Otol., Rhin. and Laryngol., September, 1912, p. 665.

13. Biggs: Brit. Med. Jour., Aug. 17, 1912, p. 348.

14. Broquin: Ann. d. mal. ven., January, 1912, p. 49.

15. Brown, A. G.: Virginia Med. Semi-Monthly, Oct. 25, 1912, p. 531.

16. Browning and Lintz: New York Med. Jour., April 20, 1912, p. 786.

17. Browning and Lintz: New York Med. Jour., July 20, 1912, p. 116.

18. Busse and Merian: München. med. Wchnschr., 1912, p. 2330.

19. De Buys: Am. Jour. Obst. and Dis. Women and Child., January, 1913 , p. 65.

20. Campbell and Patch: Canadian Med. Assn. Jour., April, 1912, p. 277.

21. Capelli : Gior. ital. d. mal, ven. e d. pelle, March 21, 1913, p. 65.

22. Carle: Ann. dermat. et de syph., March and April, 1912, p. 231.

23. Carpenter: Laryngoseope, September, 1912, p. 1104.

24. Churchill: AM. Jour. Dis. ChILd., 1912, iii, 363.

25. Comby: Arch. de méd. des Enf., Nov. 1, 1912, p. 801.

26. Cook, A. H.: New Orleans Med. and Surg. Jour., 1913, lxiv, No. 12, p. 919.

27. Corbus: Jour. Am. Med. Assn., Oct. 5, 1912, p. 1267.

28. Cronquist: München. med. Wchnschr., Sept. 3, 1912, p. 1960.

29. Cronquist: München. med. Wchnschr., September, 1912, p. 2449.

30. Davis: Jour. Cut. Dis. Incl. Syphilis, April, 1913, p. 270.

31. Dexter and Cummer: Arch. Int. Med., 1913, ix, 605.

32. Dodd, Oscar ${ }^{2}$ Abstr. Jour. Cut. Dis., January, 1913.

33. Dreyfus: München. Med. Wchnschr., 1912, lix, No. 19, p. 1027.

34. Dreyfus: München. med. Wchnschr., Aug. 20, 1912, p. 1857.

35. Eisenstaedt: New York Med. Jour., Nov. 16, 1912, p. 1014.

36. Ellis: Jour. Am. Med. Assn., 1912, lix, No. 14, p. 1263.

37. Engman: Jour. Am. Med. Assn., 1913, lviii, No. 19, p. 1415.

38. De Favento: Gior. ital. d. mal. ven. e d. pelle, June 5, 1912, p. 177.

39. Field, Cyrus: Jour. Am. Med. Assn., June 1, 1912, p. 1681.

40. Finger: Correspondence, Jour. Cut. Dis., 1913, xxx, 437.

41. Flatau: München. Med. Wchnschr., Sept. 24, 1912, p. 2102.

42. Fordyce: Jour. Cut. Dis. Incl. Syphilis, 1913, xxxi, No. 9, p. 642.

43. Fordyce: Jour. Am. Med. Assn., Oct. 5, 1912, p. 1231.

44. Fox: Jour. Am. Med. Assn., Oct. 5, 1912, p. 1243.

45. Frühwald: Wein. klin. Wchnschr., 1912, xxv, No. 16, p. 484.

46. Gardner: Jour. Cut. Dis., October, 1912, p. 616.

47. Gaucher: Presse méd., May 15, 1912, No. 40, p. 425.

48. Glogau: Ann. Otol. Rhinol. and Laryngol., September, 1912, p. 703.

49. Gougerot and Parent: Ann. d. mal. ven., January and April, 1912.

50. Gradwohl: Med. Rec., New York, 1912, lxxxi, No. 21, p. 973.

51. Greven: Pac. Med. Jour., May, 1912, Iv, No. 5, p. 286.

52. Gruenberg: Deutsch. med. Wehnsehr., Oct. 31, 1912, p. 2070.

53. Hazen, H. H.: Jour. Cut. Dis. Incl. Syph., September, 1913, p. 618.

54. Heidingsfeld: Am. Jour. Urol., 1912, No. 8, p. 434.

55. Heidingsfeld: New York Med. Jour., May 4, 1912.

56. Heidingsfeld: Jour. Am. Med. Assn., Nov. 1, 1913, p. 1598.

57. Hirsch: München. med. Wchnschr., July 23, 1912.

58. Hofer: Arch. F. Ohrenh., Nov. 28, 1912, Nos. 1 and 2, p. 117.

59. Hoffman: Deutsche. med. Wehnschr., 1913, xxxix, No. 1, p. 14.

60. Iverson: München. med. Wchnschr., 1912, lix, No. 26, p. 1436. 
61. Jeanselme and Vernes: Paris Medical, March, 1912.

62. Kall: Münch. Med. Wehnschr., July 30, 1912, p. 1710.

63. Kaplan: Med. Rec., New York, 1912, lxxi, No. 24, p. 1132.

64. Keidel and Hurwitz: Jour. Am. Med. Assn., Oct. 5, 1912, p. 1257.

65. Keyes: Jour. Cut. Dis., 1912, xxx, No. 8, p. 478.

66. King-Smith: Jour. Cut. Dis. Inel. Syph., 1913, xxxi, No. 9, p. 639.

67. Klotz: New Yorker Med. Wehnschr., June, 1912, p. 1.

68. Knapp: Arch. Ophthal., 1913, xli, No. 4, p. 235.

69. Kochmheld: München. med. Wchnschr., Aug. 13, 1912, p. 1804.

70. Lankford: Virginia Med. Semi-Monthly, 1913, xvii, No. 5, p. 108.

71. Lévy, Bing, Duroeux and Dogny: Paris mêd., February, 1912, p. 109.

72. Lévy, Bing, Dogny and Duroeux: Ann. d. mal. ven., 1912, vii, No. 5, p. 321.

73. Lévy, Bing and Duroeux: L'Enfance, January, 1913.

74. Lippmann: Dermat. Wehnschr., Feb. 22, 1913, p. 213.

75. Lorenz: Med. Rec., New York, Aug. 3, 1912, p. 185.

76. Lueders: Deutsch. med. Wchnschr., Jan. 30, 1913, p. 225.

77. Mackee: New York Derm. Soc. in Jour. Cut. Dis., 1912, xxx, No. 8, p. 482.

78. Madeira: Arch. Brasil. de Med, Feb., 1912, p. 51.

79. Marshall: Am. Jour. Child. Dis., 1912, ix, No. 3, p. 204.

80. Marshalko and Veszpremi: Arch. f. Dermat. u. Syph., 1912, cxiv, 589.

81. Mayer: Deutsch. med. Wchnschr., Nov. 14, 1912, p. 2174.

82. MeDonagh: Brit. Med. Jour., June 8, 1912, p. 1287.

83. McKinness: Med. Rec., New York, July 20, 1913, p. 100.

84. McIntosh and Parker: Lancet, liondon, July 13, 1912.

85. Merian, Girauld and Duret: Bull. d. Soc. Franc. de dermat. et de syph., May, 1913, p. 272.

86. Meyer: Dermatol. Ztsclir., 1912, Nos. 3, 4, p. 393.

87. Mortimer: New York Med. Jour., Nov. 23, 1912, p. 1072.

88. Monradian: Ophthal. Rev., August, 1912.

89. Morton: New York Med. Jour., Aug. 31, 1912, p. 425.

90. Müller: Wein. klin. Wchnschr., 1912, xxv, 872.

91. Newmark: Am. Jour. Med. Se., 1912, exliv, No. 6, p. 848.

92. Nicholas and Mutot: Ann. d. mal. ven., January, 1912, p. 1.

93. Nobl and Peller: Dermat. Wehnschr., 1913, lv, No. 30, p. 971.

94. Noeggarath: Jahrb. f. Kinderh., February, 1912, p. 131.

95. Noguchi: Canadian Med. Assn. Jour., April, 1912, p. 269.

96. Noguchi: Jour. Am. Med. Assn., lix, No. 14, p. 1262.

97. Perkins: New York State Jour. Med., xii, No. 7, p. 390.

98. Perkins: Laryngoscope, 1912, xxii, 1089.

99. Pinkus: Dermat. Ztschr., August, 1912, p. 675.

100. Pinkus: Dermat. Wehnschr., Feb. 15, 1913, p. 196.

101. Post: Jour. Am. Med. Assn., Oct. 5, 1912, p. 1240.

102. Power, D'Arcy: Brit. Med. Jour., June 22, 1912, p. 1418.

103. Ravaut: Presse méd., March 2, 1912.

104. Reese: New York State Jour. Med., 19I2, xii, No. 7, p. 393.

105. Reese: New York Med. Jour., June 29, 1912, p. 1356.

106. Reidl and Geyer: Arch. Brasil. de Med., February, 1912, p. 19.

107. Rimini: Deutsch. Med. Wchnschr., Jan. 9, 1913, p. 71 .

108. Schields: Lancet Clinic, 1912, cviii, 635.

109. Scholtz and Riebes: Dermat. Wehnschr., June 15, 1912, p. 693.

110. Schreiber: München. med. Wchnschr., Aug. 20, 1912, p. 1850.

111. Shaw: Brit. Med. Jour., April 6, 1912, p. 777.

112. Simon: München. med. Wehnschr., Oct. 22, 1912, p. 2328.

113. Spiethoff: München. med. Wchnschr., 1912, lix, No. 19, 1086.

114. Steiger: München. med. Wchnschr., Sept. 10, 1912, p, 2000.

115. Stieren: Abstr. Jour. Cut. Dis., January, 1913.

116. Stoner and Keiser: Cleveland Med. Jour., 1912, xi, No. 4, 251.

117. Strathy and Bates: Canadian Med. Jour., January, 1913, p. 32. 
118. Stühmer: München. med. Wchnsclır., Nov. 5, 1912, p. 447 .

119. Swift and Ellis: New York Med. Jour., July 13, 1912, p. 53.

120. Swift, Homer: Jour. Am. Med. Assn., Oct. 6, 1912, p. 1236.

121. Szametz: München. Med. Wchnschr., Oct. 22, 1912, p. 2333.

122. Terzaghi : Clinica Dermosifilopat. d. r. Univ. di Roma, 1912, xxs, 118.

123. Tieche: Arch. f. Derm. u. Syph., 1912, cxi, No. 2, p. 223.

124. Towle: AM. Jour. Dis. ChILd., 1912, iv, 180.

125. Trimble: Jour. Cut. Dis., December, 1912, p. 732.

126. Ullman: Arch. f. Dermat. u. Syph., 1912, cxiv, No. 2.

127. Voorhees: Am. Med., August, 1912, p. 419.

129. Wachenfeld: Dermat. Wchnschr., March 23, 1912, p. 341.

130. Watrazewski : Jour. Cut. Dis., July, 1912, p. 435.

131. Wechselmann: München. med. Wchnschr., Sept. 24, 1912, p. 2099.

132. Weil, Morel and Moriquand: Bull. d. Soc. de pédiat. de Paris, Oct. 15, 1912 , p. 332.

133. Whitehouse and Clark: Jour. Cut. Dis. Incl. Syph., 1912, xxxi, No. 9, p. 633 .

134. Wilson: New York State Jour. Med., 1912, xii, No. 3, p. 183.

135. Wolbast: New York Med. Jour., Feb. 22, 1913, p. 378.

136. Wolff and Miilzer: München. med. Wehnschr., July, 30, 1912, p. 1706.

137. Zimmern: Berl. klin. Wehnschr., 1912, xlix, No. 23, p. 1088.

138. Welde: Ztschr. f. Kinderh., May 15, 1913, p. $45 \mathrm{I}$. 